проф. др Александра Б. Вранеш*

Универзитет у Београду

Филолошки факултет**

\title{
БИБЛИОТЕКА И УНИВЕРЗИТЕТ ${ }^{1}$
}

\section{Сажетак}

„Универзитет је заједница предавача и студената удружених у процесу тражења истине" ${ }^{2}$, присећамо се речи Карла Јасперса. Или оних Метјуа Арнолда: да је он „дом изгубљених принципа и веровања, непознатих имена и несхватљиве оданости". ${ }^{3}$ Универзитетски библиотекар Ели М. Оболер прокоментарисао је осамдесетих година, са осетним незадовољством због тадашњег стања, претходно поређење Метјуа Арнолда: „Универзитет, посебно државни универзитет, данас је исувише често дом општеприхваћених принципа, уобичајених веровања, (где је) оданост сасвим обична и конформистичка".

За Л. Р. Вилсона и Мориса Тобера, америчке теоретичаре библиотекарства, основне функције универзитета огледају се кроз „конзервацију знања, образовање, истраживање, публиковање, услуживање информацијама и интерпретацију идеја". ${ }^{5}$ „Партнерство у прогресу” је један од елемената чије постојање води померању граница универзитета. Други је да наставници и студенти треба да „охрабрују и шире идеје прошлог, садашњег и будућег времена”. Универзитет садашњице треба да буде профилисан према потребама савременог друштва, а од библиотеке, која је симболично названа „срцем универзите-

\footnotetext{
* Филолошки факултет, Студентски трг 3, 11000 Београд aleksandra.vranes@gmail.com; aleksandra.vranes@fil.bg.ac.rs Назив пројекта: Књиженство - теорија и историја женске књижевности на српском језику до 1915. год. Евиденциони број пројекта: 178029.

1 Текст претходно делом објављен у књизи: Високошколске библиотеке/ Александра Вранеш.. - Београд : УБ „Светозар Марковић“, 2004. - стр. 15-29.

2 The Idea of the University / Karl Jaspers. - Owen, 1959. - Стр. 19.

3 Ideas and the University Library : Essays of an Unortodox Academic Librarian / Eli M. Oboler. - Westport, London : Greenwood Press, 1976. - Стр. 14.

$4 \quad$ Ibid.

5 The University Library / Louis Round Wilson, Maurice F. Tauber. - 2nd ed. - Columbia U.P., 1975. - Стр. 16-17.
} 
та", очекује се да се прилагођава свим променама у наставном и научно-истраживачком процесу.

Кључне речи: универзитет, библиотека, настава, научна истраживања.

„Универзитет је заједница предавача и студената удружених у процесу тражења истине" ${ }^{1}$, присећамо се речи Карла Јасперса. Или оних Метјуа Арнолда: да је он „дом изгубљених принципа и веровања, непознатих имена и несхватљиве оданости". Универзитетски библиотекар Ели М. Оболер прокоментарисао је осамдесетих година, са осетним незадовољством због тадашњег стања, претходно поређење Метјуа Арнолда: „Универзитет, посебно државни универзитет, данас је исувише често дом општеприхваћених принципа, уобичајених веровања, (где је) оданост сасвим обична и конформистичка". ${ }^{3}$ Lord Annan сматра да се на универзитету промовише „кроз размишљања и истраживања живот разума" ${ }^{\prime 4}$ и преноси култура из једне генерације у другу.

За Л. Р. Вилсона и Мориса Тобера, америчке теоретичаре библиотекарства, основне функције универзитета огледају се кроз „конзервацију знања, образовање, истраживање, публиковање, услуживање информацијама и интерпретацију идеја". ${ }^{5}$

Од Robbins-овог извештаја о високом образовању у Великој Британији из 1963. године ${ }^{6}$, којим се уводи могућност постојања отвореног универзитетског система, којим се минимализује важност формалних образовних квалификација, а васпитно-образовни процес употпуњава коришћењем телевизијских и радио емисија, аудиовизуелне и остале некњижне грађе, до данашњег реформисаног, тзв. "болоњског“ универзитета, и још више учења на даљину, протекле су деценије тражења одговора на питања везана за најуспешнију методологију предавања, учења и истраживања, за проширивање,

1 The Idea of the University / Karl Jaspers. - Owen, 1959. - Стр. 19.

2 Ideas and the University Library : Essays of an Unortodox Academic Librarian / Eli M. Oboler. - Westport, London : Greenwood Press, 1976. - Стр. 14.

$3 \quad$ Ibid.

4 The University in Britain / Lord Annan // Universities for a Changing World / ed. Michael D. Stephens, Gordon W. Roderich. - David and Charles, 1975. - Стр. 19.

5 The University Library / Louis Round Wilson, Maurice F. Tauber. - 2nd ed. - Columbia U.P., 1975. - Стр. 16-17.

$6 \quad$ University Grants Committee : Robbins Report. - London, 1963. 
сужавање и реинтерпретацију историјских догађаја и теоријских проблема, а више него икада потврђена је „визија британског библиотекара Eli Oboler-a о универзитету будућности, који за своје границе треба да има цео свет.“

"Партнерство у прогресу" је један од елемената чије постојање води померању граница универзитета. Други је да наставници и студенти треба да „охрабрују и шире идеје прошлог, садашњег и будућег времена". Универзитет садашњице треба да буде профилисан према потребама савременог друштва, а од библиотеке, која је симболично названа "срцем универзитета”, очекује се да се прилагођава свим променама у наставном и научно-истраживачком процесу. Из тога произилази и коментар Michael Beloff-а у књизи The plateglass universities да факултети више нису куле од слоноваче, него акваријуми са златним рибицама. ${ }^{7}$

У студији Allen-a Booz-a Problems in University library management, 8 израђеној за потребе Удружења истраживачких библиотека Вашингтона 1970. године, истиче се и све израженије укључивање универзитета у друштвени живот. Библиотека у потпуности одражава проблеме, захтеве и циљеве универзитета, што је Thomas Carlyle сажео у следећем исказу „прави универзитет је збирка књига”. ${ }^{9}$ Дефиниција би, сматра Norman Higham, била тачнија да је Carlyle универзитет окарактерисао као збирку књига и читалаца, јер универзитет као и библиотека, треба да буде активан чинилац друштва, што је могуће постићи само ако постоји изграђен систем комуникација, како читалаца са књигом, тако и међу самим читаоцима. То је и разлог што се у савременој теорији библиотекарства све чешће осамдесетих година користи термин „образовна”, или „наставна библиотека”, чијем је значењу посвећена студија The Academic Library as a Teaching Library: a role for the 1980's. ${ }^{10}$

7 The Plateglass Universities / Michael Beloff. - London : Secker and Warburg, 1968.

8 Problems in University Library Management : a Study Conducted by Booz, Allen and Hamilton, Inc., for the Association of Research Libraries and the American Council on Education / Allen Booz. - Washington : Association of Research Libraries, 1970. - Стр. 124-128.

$9 \quad$ Heroes and hero - Workship : the Hero as Man of Letters / Thomas Carlyle.

10 The Academic Library as a Teaching Library // Role for the 1980's / Alan E. Guskin, Carla J. Stoffle, Joseph A. Boisse. - U : Library Trends. - 28 (1979/80). - Стр. 228.

Alan Guskin, Carla Stoffle и Joseph Boisse карактеришу овај тип библиотека са шест основних задатака: 1. обавеза обучавања студената, наставника и осталих корисника библиотека за ефикасно коришћење информационих извора; 2. обавеза да информациони извори пруже подршку развоју студената у грађане који ће се и убудуће перманентно образовати; 3. обавеза отварања библиотеке ка припадницима других заједница, 
Положај библиотеке на универзитету зависи, како од библиотекара, тако и од наставника и студената, а све новине за које се залажу поменути аутори могуће је спровести кроз тимски рад, који почива на чврстој сарадњи свих академских слојева, чији је, сматра Allen Booz ${ }^{11}$, битан сегмент планирање. Ефикасно планирање је теже спровести на универзитету него у другим институцијама, јер се оно супротставља универзитетским слободама и потребама тренутка.

Библиотека треба да одговори захтевима универзитета, а то је могуће само ако се успостави флексибилнији однос према текућим наставним потребама. Ronald Benge наглашава да свака библиотека има одређени степен одговорности у настави, али у академским библиотекама то мора бити од изванредне важности. ${ }^{12}$

а не само универзитета; 4. обавеза образовања чланова осталих институција у циљу бољег искоришћавања информационих извора, које библиотека поседује; 5. обавеза одржавања збирке библиотеке, тако да она обезбеђује задовољавање основних потреба корисника на универзитету; 6 . обезбеђење међубиблиотечке сарадње како би корисник добио и публикације којих нема у библиотеци. Сва наведена задужења, којима се описује целокупна библиотечка делатност на универзитету, формулисана су кроз призму односа библиотеке према кориснику.

11 Problems in University Library Management : a Study Conducted by Booz, Allen and Hamilton, Inc., for the Association of Research Libraries and the American Council on Education / Allen Booz. - Washington : ARL, 1970. - Стр. 22.

Allen Booz наводи кључне особине доброг планирања: 1. подударност функције универзитета и библиотеке; 2. комуникативност наставног, ненаставног особљQа и студената; 3. систематичност; 4. максимална применљивост плана; 5. флексибилност с обзиром на сталне иновације у настави; 6. оријентисаност на акцију; 7. јасноћа и сажетост; 8. документованост. Овакве особине могу поседовати само планови у чијој изради учествује квалификован и искусан библиотечки кадар, који је свестан чињенице да је планирање поуздана основа за развој и ефикасна контрола сопствене будућности. При планирању се посебна пажња мора посветити идентификовању група корисника и њихових потреба, као и могућности библиотеке да те захтеве задовољи на основу свога фонда и испитивању способности библиотечких радника да испуњавају задатке које им истовремено намећу традиционална организација и нови програми развоја библиотеке. Ефикасност и доследност испуњавања тих задатака преиспитују се кроз свакодневне радне процесе и повремене анализе, а степен њихове остварености специфичан је за сваку појединачну академску библиотеку. Вештина библиотечког кадра огледа се управо у његовој способности да евалуира постигнуте резултате на основу објективних, па чак и субјективних показатеља, и, по потреби, мења развојну политику библиотеке чије усаглашавање са политичком и административном страном живота на универзитету има одлучујућу улогу.

12 Libraries and Cultural Change / Ronald C. Benge. - London : Clive Bingley ; Hamden : Archon Books, 1972. - Стр. 226. 
Универзитетске библиотеке, које су у предратном периоду биле више окренуте решавању проблема унутрашње организације, сада пажњу усмеравају, пре свега, на побољшање односа са читаоцима и на укључивање у васпитно-образовни процес. То је и разлог што М.А. Gelfand у књизи University libraries for developing countries закључује да су академске библиотеке „динамични инструменти образовања”. ${ }^{13}$ Поједини теоретичари, попут Herbert-a Goldhor-a, Harold-a Lancour-a и Haward-a Williams-a, активно укључивање библиотека у наставу виде као трећи степен развоја академске библиотечке делатности, који је уследио после „периода прикупљања и чувања грађе”, када се вредност библиотеке мерила бројем књига које поседује, и када се њен значај утврђивао бројем услужених корисника. Све функције академске библиотеке Paul Buck је обухватио речју „одговорност”, којом је указао на потребу да библиотека у потпуности задовољи захтеве универзитета. До закључка да задаци библиотеке директно зависе од задатака, циљева и планова наставе и научног рада на универзитету дошао је седамдесетих година и Allan Booz. Oн је покренуо и питање вредновања резултата рада библиотеке на које је тешко наћи одговор с обзиром да је библиотека, пре свега, „професионална институција за услуживање корисника, не фабричка производна линија", ${ }^{14}$ те, стога, постојеће статистике о набавци, циркулацији библиотечког материјала и информисању корисника често нису реални показатељи њеног рада.

Студију о унутрашњој организацији библиотека Problems in university library management ${ }^{15}$ начинило је Удружење истраживачких библиотека из Вашингтона на основу анализе шест америчких универзитета (Cornell University, Duke University University of California - Los Angeles, University of Connecticut, University of lowa, University of Pennsylvania). Кроз сто педесет интервјуа са директорима и особљем библиотека, наставницима и студентима, дошло се до општих закључак

13 University Libraries for Developing Countries / M. A. Gelfand. - Paris : UNESCO, 1968. - CTp. 25. - (UNESCO Manuals for Libraries; 14).

14 Problems in University Library Management : a Study Conducted by Booz, Allan and Hamilton, Inc, for the Association of Research Libraries and the American Council on Education /Allen Booz. - Washington : ARL, 1970. - Стp. 26.

15 Problems in University Library Management / Allen Booz. - Washington : ARL, 1970. - Стp. 21-41. 
да се пословање библиотека одвија кроз три службе: за набавку, обраду и издавање библиотечког материјала; да је организација библиотека пирамидалног облика; и да не постоји одговарајућа, ни константна комуникација између појединих служби, као ни између руководећег и радног кадра.

Овакав тип организације библиотеке је традиционалан и највише изложен критици. У њему Nicolas Burckes ${ }^{16}$ види негативан подстицај за развијање бирократије и изолованих група радника, што аутоматски смањује ефикасност пословања библиотеке. На исти начин, размишљали су, и пре Burckee-a, Frederic Taylor, Elton Mayo, Douglas Mc Grega, Kensis Likert, Peter Drucker и Frederic Herrberg, који наглашавају потребу библиотеке да се определи за облик организације, која њеним службеницима омогућава равноправност у одлучивању, што води појачаној мотивацији за обављање појединих послова, а самим тим и повећању продуктивности рада. Kensis Likert, стога, уместо „ауторитативног” истиче „групно” одлучивање у библиотеци. ${ }^{17}$

Овај проблем иницирао је и израду докторских дисертација аутоpa Henry Stewart-a ${ }^{18}$ и Maurice Marchant ${ }^{19}$, који су, због једносмерности у доказивању свога виђења, касније били критиковани. Nicolas C. Burckee 20, аутор врло исцрпног чланка Participatory management in Academic Libraries, који је, у ствари, историјски преглед теорија руковођења, заступа становиште да партиципација у управљању не решава све проблеме у библиотеци, можда, чак, не повећава ни ефективност, у име које је дефинисана. У циљу потврде свог мишљења он подсећа на речи Louis-a Kaplan-a о негативним резултатима таквог одлучивања: „Појединци чије је мишљење група одбила, могу се из ње издвојити. Процес групног одлучивања може бити фрустрирајући за неколицину њених чланова. Мада појединци могу допринети кохезивности групе, њихова делатност може бити и сасвим супротна". ${ }^{21}$ Eli M. Oboler као основни предуслов за добру организацију библиотеке наводи потребу за

16 Participatory Management in Academic Libraries : a Review / Nicolas C. Burckee // College and Research Libraries. - Vol. 45, no 1 (january 1984), стр. 25-34.

17 Ibid. - Стр. 27.

18 Ibid. - Стр. 28.

19 Ibid.

20 Ibid. - Стр. 30.

21 Ibid. - Стр. 31. 
интелектуалном слободом сваког библиотекара,,22 док, насупрот њему, James Michalko ефикасност организације и пословања сматра зависном од степена сарадње међу библиотекарима. ${ }^{23}$

Разноврсност тумачења овога проблема и неадекватност постојеће организације библиотека друштвеним потребама били су повод да ARL (Association of Research Libraries) формулише неколико препорука, које би допринеле побољшању организације и пословања библиотека. ${ }^{24}$

Harrison Bryan ${ }^{25}$ сматра да је једини прави начин за постизање високог квалитета свих радних процеса, проистекао из праксе, која је осамдесетих година уведена у универзитетске библиотеке, а која се, заправо, односи на увођење новог принципа организације библиотеке, не према функцијама одељења, већ према предмету, било да се то односи на област научног истраживања (физика, математика), или на врсту грађе (аудио-визуелни материјал, архивска грађа). K.W. Neal ${ }^{26}$

22 Ideas and the University Library : Essays of an Unortodox Academic Librarian / Eli M. Oboler. - London, Westport : Greenwood Press, 1976. - Стр. 27. - (Contributions in Librarianship and Information Science; 20).

Ibid. - Стp. 11-27.

24 Problems of University Library Management : a Study Conducted by Booz, Allen and Hamilton, Inc. for the Association of Research Libraries and the American Council and Education / Allen Booz. - Washington : ARL, 1970. - Стр. 71. Препоруке су врло широко постављене и везане за све процесе у библиотечкој делатности: 1. дефинисати библиотечку организацију тако да задовољи текуће захтеве корисника; 2. вредновати постојеће узоре организације библиотека у светлу измењених захтева корисника и наставе; 3. описати тип и функције библиотеке, као и број потребног особља; 4. вредновати и оживети канале комуникације између библиотека, библиотечког особља, као и предавача, студената, универзитетске и библиотечке управе; 5. развити алтернативне планове организације библиотека, њених циљева, способности квалификованог библиотечког кадра и потреба библиотекара за професионалним усавршавањем.

25 University Libraries in Britain : a new look / Harrison Bryan. - London : Clive Bingley; Hamden : Linnet Books, 1976. - Стр. 74.

26 British University Libraries / K. W. Neal. - Wilmslow : author, 1971. - Стр. 25-37.

1. Предметни специјалиста поседује обимно знање из одређеног предмета па може суверено да обавља послове набавке, обраде и издавања библиотечког материјала за ту област; 2. он може да оствари успешну сарадњу са представницима сродних факултетских библиотека; 3. процеси каталогизације, класификације библиотечког материјала и информисања корисника, у том случају, обављају се без стручних пропуста; 4. управљање библиотеком није препуштено ужем кругу људи, што је случај са функционалном организацијом библиотека, већ сви предметни специјалисти, представници појединих одељења, у њему учествују равноправно са директором библиотеке. K.W. Neal je, истовремено, свестан и недостатака оваквог система организације, па о њима расправља 
рашчлањује основне позитивне и негативне карактеристике оваквог приступа.

Поменутим примедбама K.W. Neal-a, пракса је придружила још једну: оваква организација увећава трошкове пословања библиотеке, што је велики минус фактор поменутог система с обзиром на скромна финансијска средства која друштво издваја за библиотеке. То је и био разлог, како потврђује истраживање Harrison-a Bryan-a, што су библиотеке Leeds-a, Sussex-a, Leicester-a, York-a, Kent-a i Essex-a, одбациле „предметни принцип” и вратиле се традиционалном управљању према функцији и осамостаљивању служби за набавку, обраду и издавање библиотечког материјала у складу са основним радним процесима у библиотеци.

До скора се мисији библиотеке приступало на традиционалан начин, а данас се за њено испуњавање очекују: сарадња, интерактивност, интердисциплинарност, мултифункционалност, мултимедијалност, динамичност, брзина, доступност, претраживост, те скуп ових особина и активности наводи савремене теоретичаре да такву библиотеку назову виртуелном или постмодерном. Библиотека, свака, па и она на универзитету, а временом ће то бити све више, излази из оквира централизоване, физички омеђене, статичке, формално организоване јединице и добија епитете проблемски оријентисане, технолошки напредне, удруживању захваљујући финансијски неспутане, ефикасне и професионалне институције.

У пројектима које су предлагале међународне или локалне заједнице и организације, библиотеке су се у периоду од шездесетих до осамдесетих година 20. века окупљале око појединих идеја, какве су у оквиру IFLA-e (International Federation of Library Associations), биле: обједињена набавка, међународна стандардизација каталошког и библиографског описа, међународно јединствено нумерисање

веома објективно: 1. предметни специјалиста може добро познавати највише две до три научне области, а ретко више од 2 до 3 страна језика - то је разлог што у великој универзитетској библиотеци мора бити запослено више стручњака различитих профила; 2. предметни специјалиста није подједнако вешт у обављању свих библиотечких послова; 3. он има склоност ка мењању опште прихваћених класификационих схема; 4. пошто мора стално да буде на услузи корисницима, предметни специјалиста нема довољно времена да се бави научно-истраживачким радом, што се од њега неоспорно очекује; 5. пошто наука тежи интердисциплинарности, тешко је утврдити делокруг рада сваког предметног специјалисте. 
серијских и монографских публикација, увођење каталогизације у публикацији, развијање међубиблиотечке позајмице, универзална библиографска контрола, универзална доступност публикација, заштита и конзервација библиотечке грађе, узајамна каталогизација, поштовање ауторских права, универзални проток података и телекомуникација.

Почетак седамдесетих година 20. века обележила је и нова иницијатива оснивања конзорцијума библиотека (присутна у литератури још од педесетих), који представљају слободнију заједницу чланица и могу обједињавати све претходне облике удруживања, гранско и функционално, али и географско, демографско, регионално, стручно. Технолошки напредак сигурно није проузроковао појављивање конзорцијума (који су као облик удруживања познати у привреди, економији и образовању још од средине 19. века), али их деведесетих година јесте олакшао, убрзао и допринео распрострањености и комплексности њиховог пословања. И конзорцијум и дигитална библиотека зависе од образовања и професионалне посвећености библиотекара. У поздравној и визионарској речи при отварању међународног сајма књига још 1935. године Хосе Ортега предвиђа: «Библиотекар ће у будућности морати да усмерава неупућеног читаоца кроз неопходну џунглу књига и да буде терапеут, хигијеничар његове лектире.»

Обим, комплексност и различитост информација надрастали су способности појединаца и фондове библиотека, самим тим и дотадашња поларизована схватања о библиотекарима као универзалним зналцима, или предметним специјалистима.

Са укључивањем нових медија у фондове библиотека јавила се и потреба за усаглашавањем терминологије, па су употребљавани појмови медијатека, фонотека, фототека. Сличном процесу и данас присуствујемо у енглеском језику, у коме синтагму «teaching library» у стопу прати израз "teaching суbrary»" 27 тренутно непреводив на српски, који означава и наставу за коришћење информационе технологије и употребу информационе технологије у настави. Не само терминолошки, већ и суштински, овај процес започет је на University of Southern California 1994. године, пратећи и новом распо-

27 Junling, Peng and He Haidi: The Application of Modern Information Technologies and the Intensification of the Education Function for Academic Libraries. - http://www.lib.pku. edu.cn/98conf/paper/a/PengJunling.htm. - 15.03.2004. - p.2 
делом простора другачији приступ схватању улоге библиотеке. Наиме, простор у коме се може остваривати међусобна комуникација студената, наставног и библиотечког особља уз помоћ савремене компјутерске опреме, најновијег софтвера и особља за техничку подршку, два пута је већи од магацинског простора библиотеке. Све то делује подстицајно на увођење иновација у саму наставу, те библиотека служи као експериментални полигон. Обједињавањем две функције библиотека, образовне и забавне, дошло се чак до стварања новог термина који овај неочекивани квалитативни спој означава, «edutainment», мада за сада остаје непреводив у нашем језику. Можда ће на следећој деоници пута којим су кренули библиотекари и информатичари као потврда и признање стајати и нови синтагматски спој који означава неку нову професију.

Било да проучавају библиотеку и универзитет као самосталне целине, или у међусобном односу, било да говоре о стручном кадру ових институција и о релацијама између библиотекара и наставника, сви поменути теоретичари библиотекарства слажу се у једном: библиотека и универзитет се узајамно условљавају и одређују. Мада је библиотека настала чак и пре првог универзитета, чини се као да је у новије време свест о њеном значају потиснута. Сва претходна наведена мишљења теже да библиотеци врате пређашњу улогу у образовном и научно-истраживачком процесу. Библиотека сасвим сигурно више не може да буде „хранилиште књига”, нити „помоћна институција” која само опслужује корисника грађом. Њој је намењена улога активног учесника друштвеног, наставног, научног живота на универзитету. Она постаје интегрални, незаменљиви део универзитета, на коме професори не могу обављати ни педагошки, а камоли озбиљан научни, рад без коришћења њених фондова и информација. Управо у стварању тих информација огледа се најважнији облик делатности универзитетског библиотекара. У данашње време експлозије научних издања наставник није у стању да ажурно прати и набавља сву ту грађу. Његов рад је рад појединца, док је библиотечка делатност саткана од тимског, колективног рада, који је основно одређење времена у коме живимо. Овоме се придружују још два значајна достигнућа двадесетог века: интердисциплинарни приступ проблемима и омогућавање доступности база података. Универзитет данашњице може да опстане само ако сарађује са библиотеком. 


\section{Култура универзитета и филологија}

\section{Литература:}

The Idea of the University / Karl Jaspers. - Owen, 1959.

Problems of University Library Management : a Study Conducted by Booz, Allen and Hamilton, Inc. for the Association of Research Libraries and the American Council and Education / Allen Booz. - Washington : ARL, 1970.

Libraries and Cultural Change / Ronald C. Benge. - London : Clive Bingley ; Hamden : Archon Books, 1972.

The University in Britain / Lord Annan // Universities for a Changing World / ed. Michael D. Stephens, Gordon W. Roderich. - David and Charles, 1975.

Ideas and the University Library : Essays of an Unortodox Academic Librarian / Eli M. Oboler. - Westport, London : Greenwood Press, 1976.

The University Library / Louis Round Wilson, Maurice F. Tauber. - 2nd ed. - Columbia U.P., 1975.

Participatory Management in Academic Libraries : a Review / Nicolas C. Burckee // College and Research Libraries. - Vol. 45, no 1 (january 1984)

Високошколске библиотеке / Александра Вранеш. - Београд : УБ „Светозар Марковић“, 2004.

Junling, Peng and He Haidi: The Application of Modern Information Technologies and the Intensification of the Education Function for Academic Libraries. - http://www. lib.pku.edu.cn/98conf/paper/a/PengJunling.htm. - 15.03.2004.

Libraries for Users : services in academic libraries / Luisa Alvite and Leticia Barrionuevo. - Oxford [etc.] : Chandos Publishing, 2011. - XIII, 204 str. : ilustr. ; 24 cm. - (Chandos Information Professional Serie.

CAREER transitions for librarians : proven strategies for moving to another type of library / edited by Davis Erin Anderson and Raymond Pun. - Lanham : Rowman \& Littlefield, [2016] . 


\author{
Aleksandra Vraneš, PhD \\ University of Belgrade \\ Faculty of Philology
}

\title{
LIBRARY AND UNIVERSITY
}

\section{Summary}

"The University is a community of lecturers and students involved in the process of seeking the truth"28, we recall the words of Karl Jaspers. Or those of Matthew Arnold: that university is " the home of lost principles and beliefs, unknown names and incomprehensible loyalty"29. University Librarian, Eli M. Oboler commented on the eighties, with visible satisfaction with the situation at the time, previous comparison of Matthew Arnold: "University, especially state university today is too often the home of universally accepted principles, common beliefs, (where) loyalty is quite ordinary and conformist" ${ }^{\prime 30}$

For L.R. Wilson and Morris Tober, American theoreticians of librarianship, basic functions of the university are reflected through "knowledge conservation, education, research, publishing, information retrieval, and interpretation of the name" ${ }^{31}$. "Partnership is in progress" one of the elements whose existence is leading the movement of the borders of the university. The other is that teachers and students should "encourage and extend the ideas of the past, present and future times". University of the present should be profiled according to the needs of a modern society, and from a library that is symbolically called" the heart of the university", it is expected to adapt to all changes in the teaching and scientific-research process.

Key words: university, library, teaching, scientific research.

28 The Idea of the University / Karl Jaspers. - Owen, 1959. - Str. 19.

29 Ideas and the University Library : Essays of an Unortodox Academic Librarian / Eli M. Oboler. - Westport, London : Greenwood Press, 1976. - Str. 14.

30 Ibid.

31 The University Library / Louis Round Wilson, Maurice F. Tauber. - $2^{\text {nd }}$ ed. - Columbia U.P., 1975. - Str. 16-17. 